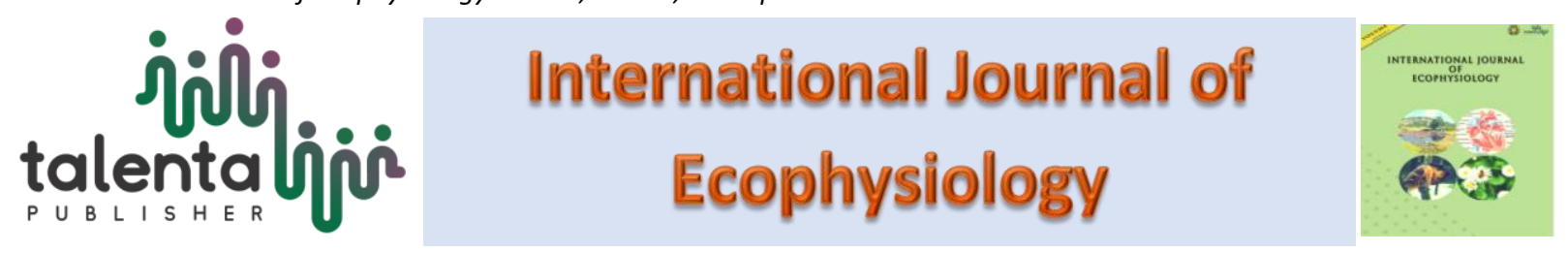

\title{
Effect of Nanoherbal Haramonting (Rhodomyrtus tomentosa) on Lungs Histology
}

\author{
Syafruddin Ilyas ${ }^{1}$, Putri Cahaya Situmorang ${ }^{1}$, Salomo Hutahaean ${ }^{1}$ \\ Rosidah $^{2}$ \\ ${ }^{I}$ Department of Biology, Faculty of Mathematics and Natural Sciences, Universitas Sumatera Utara, \\ Medan, Indonesia, 20155 \\ ${ }^{2}$ Faculty of Pharmacy, Universitas Sumatera Utara, Jalan Dr.Mansyur Medan, Indonesia, 20155
}

\begin{abstract}
The study aim to know to effect of Nanoherbal Rhodomyrtus tomentosa (Haramonting) on lungs histology of Mus musculus. Haramonting in Indonesia as a new source of health-promoting compounds such as dietary fibers, essential fatty acids, and phenolic compounds because there are 19 phenolic compounds including stilbenes and ellagitannins as major components, followed by anthocyanins, flavonols, and gallic acid. Haramonting is made on a nanoscale using High Energy Milling (HEM). This research use the Completely Randomized Design (CRD) at dosage of $(100 ; 141,42 ; 200 ; 282,82$; $400) \mathrm{mg} / 20 \mathrm{~g}$ body weight. The lungs were made into preparations by using the paraffin method and Hematoxylin Erlich-Eosin staining (HE). There were a significant difference $(\mathrm{P}<0,05)$ between control group and treatment groups on form of lung cells although no significant in lung weight.
\end{abstract}

Keyword: Nanoherbal, Rhodomyrtus tomentosa, Lungs, Alveolus, Histology

Received 2 November 2019 | Revised 20 December2019| Accepted 27 January2020

\section{Introduction}

Rhodomyrtus tomentosa in Indonesia, especially in North Sumatra, is called haramonting Rhodomyrtus tomentosa (Aiton) Hassk. (Family Myrtaceae) is an ornamental, evergreen shrub grows up to four meters tall. This plant species is native to southern and southeastern Asia [1]. The discoveries reported in the study highlight the potential of R.tomentosa as a new source of health-promoting compounds such as dietary fibers, essential fatty acids, and phenolic compounds. A total of 19 phenolic compounds were tentatively characterized, including stilbenes and ellagitannins as major components, followed by anthocyanins, flavonols, and gallic acid. Piceatannol, a promising health-promoting stilbene component [2]. Studies on haramonting mainly focused on the bioactive compounds from leaves and aerial parts because

*Corresponding author at: Jl. Bioteknologi No. 1 Kampus Univ. Sumatera Utara, Padang Bulan, Medan, Indonesia 
of their antibacterial, DNA damage prevention, and antioxidant activities [3]. In vitro antioxidant activity of the different extracts of haramonting has been reported by different methods [4].

Herbal medicines have less adverse effects as compared with modern medicines. The delivery of plant/herbal therapeutic molecules as drugs is problematic due to poor solubility, poor permeability, low bioavailability, instability in biological milieu and extensive first pass metabolism [5]. However, using Nanoherbal of haramonting has not been done on lungs. So in this study, we examined to lungs after giving nanoherbal haramonting. So, Nanoherbal haramonting as a new alternative in the treatment, expecially problem in lung.

\section{Materials and Methods}

Mus musculus from Animal house Universitas Sumatera Utara. This research use the Completely Randomized Design (CRD) using 30 male mice with an average weight of 20-25g age 12-18 weeks. Haramonting is made into a nanoscale using High Energy Milling (HEM), then inserted into the jar container, Inserting balls with larger diameter size then continued by inserting small balls and the last sample and HEM is turned on for 2 hours [6]. The treatment consisted of 6 groups consisting of 5 male mice ie Control and Nanoherbal haramonting at dosage of $(100 ; 141,42 ; 200 ; 282,82$ and 400)mg/20g body weight (LD50) in 14 days, then killed by the method of disclasio cervicalis to take the kidney. Preparation of histologist by paraffin method and Hematoxylin Erlich-Eosin staining (HE) to observe the lung cells and then the data processed with SPSS 22 program with Kruskal Wallis test.

\section{Result and Discussion}

Administration of nanoherbal haramonting in lung were significant differences between the control groups with each treatment $(\mathrm{P}<0.05)$ in several dose (Figure 1). Nanoherbal haramonting administration was not significantly different in weight of lung $(\mathrm{P}>0,05)$ (Table 1). Observations were made with 5 times the field of view by observing the Alveolus Membrane (observe the integrity of the nucleus, a membrane complete with endhotelium cells), Lumen Alveolus (Proportional size and shape) and density (relationship between alveoli) with Score 1: $>75 \%$; Score 2: 25-75\%; and Score 3: $<25 \%$.

Based on histological observations it can be seen that Control, T1 and T2 have thickened alveolar membrane but different on the size of the lumen and alveolar density. But in the treatment of T3, T4 and T5, the relationship between the alveoli is stretched, the cell nucleus fades and the cell membrane is thinning (Figure 2). 


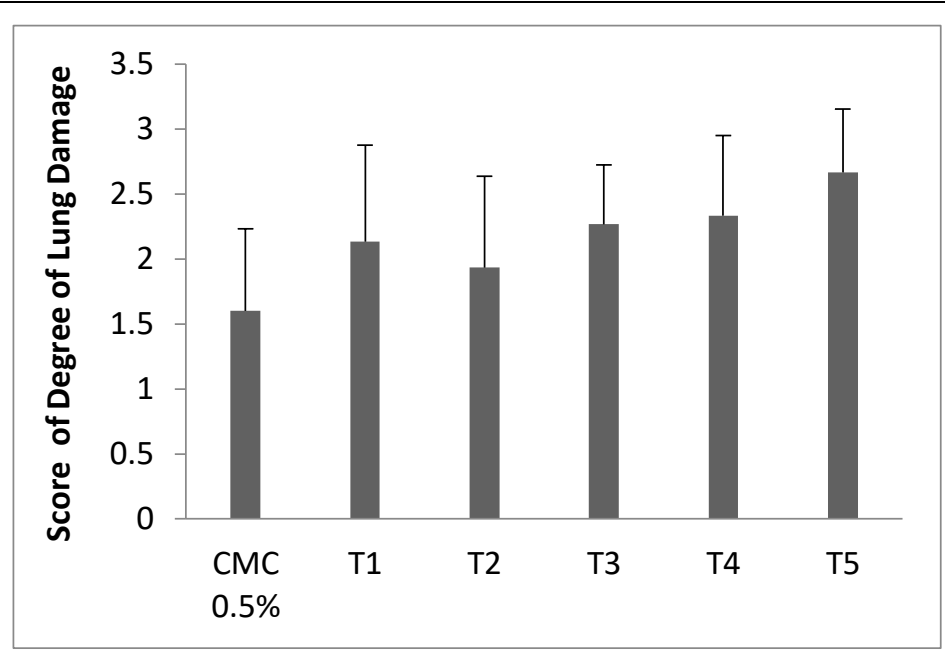

Figure 1. Degree of Lung damage ( $\bar{X} \pm \mathrm{SD}$ ). Note: $\mathrm{T} 1=100 \mathrm{mg} / \mathrm{kgBW}, \mathrm{T} 2=141.42 \mathrm{mg} / \mathrm{kgBW}$, $\mathrm{T} 3=200 \mathrm{mg} / \mathrm{kgBW}, \mathrm{T} 4=28.82 \mathrm{mg} / \mathrm{kgBW}, \mathrm{T} 5=400 \mathrm{mg} / \mathrm{kgBW}$

Table 1. Average of Lung weight

\begin{tabular}{cc}
\hline Groups & Lung Weight \\
\hline C & $8.116 \pm 0.098$ \\
T1 & $8.224 \pm 0.441$ \\
T2 & $8.200 \pm 0.732$ \\
T3 & $8.332 \pm 0.100$ \\
T4 & $8.702 \pm 0.398$ \\
T5 & $8.813 \pm 0.418$ \\
\hline
\end{tabular}
NOTE: $\mathrm{T} 1=100 \mathrm{mg} / \mathrm{kgBW}, \mathrm{T} 2=141.42 \mathrm{mg} / \mathrm{kgBW}, \mathrm{T} 3=200 \mathrm{mg} / \mathrm{kgBW}, \mathrm{T} 4=28.82 \mathrm{mg} / \mathrm{kgBW}, \mathrm{T} 5=400$ $\mathrm{mg} / \mathrm{kgBW}$
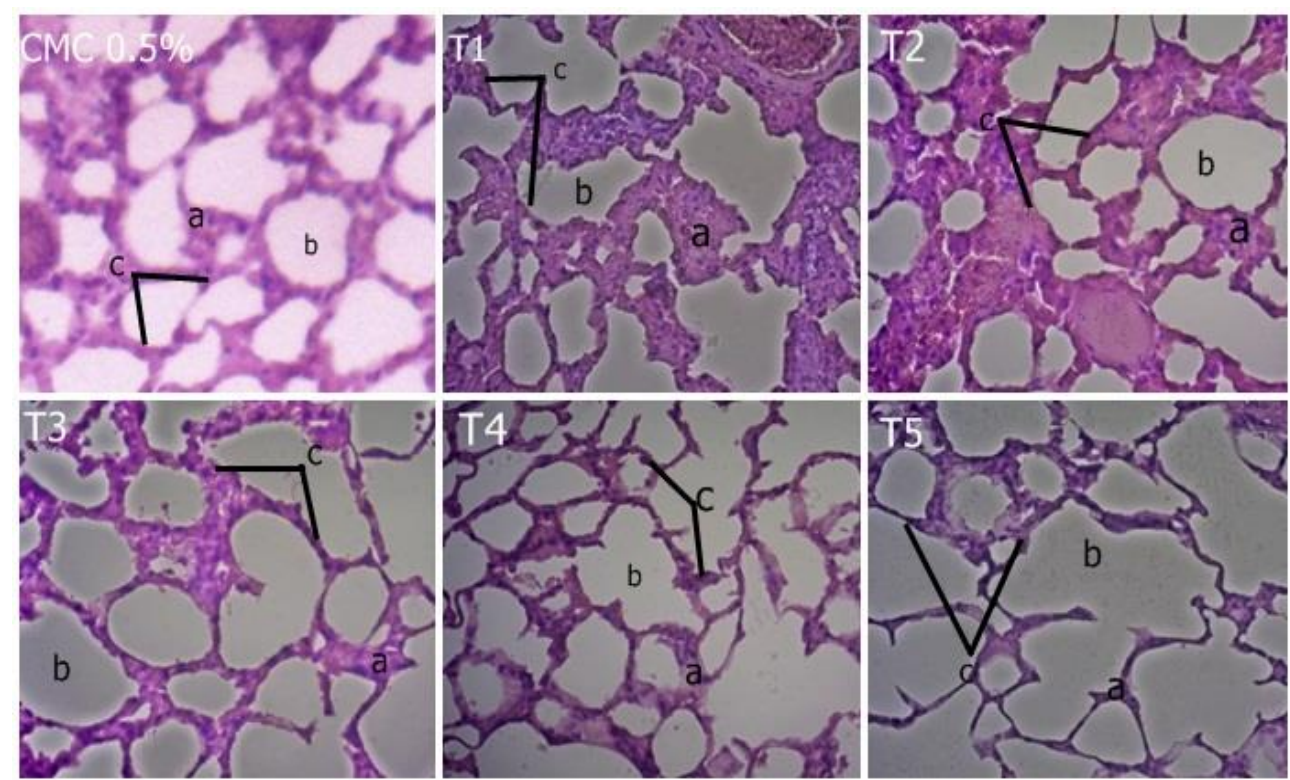

Figure 2. Histology of lung after giving Nanoherbal Haramonting, a.Membrane, b. Lumen, c. Relationship between Lumen (40x). T1 $=100 \mathrm{mg} / \mathrm{kgBW}, \mathrm{T} 2=141.42 \mathrm{mg} / \mathrm{kgBW}, \mathrm{T} 3=200$ $\mathrm{mg} / \mathrm{kgBW}, \mathrm{T} 4=28.82 \mathrm{mg} / \mathrm{kgBW}, \mathrm{T} 5=400 \mathrm{mg} / \mathrm{kgBW}$

Alveolar density in T3 to T5 treatment has histological features whose damage is almost similar. Thickening occurs in T1 and T2 treatments. But in T1, the thickening of the membrane causes a non-proportional lumen shape (Figure 2). So the degree of T1 damage is higher than T2. The highest damage occurs at T5 (Figures 1 and 2) which are the highest doses. 
The form histological structure of lung are certainly affected by compounds in the body. Haramonting has secondary metabolites such as phenols, flavonoids, saponins, tannins, steroids and triterpenoids. Phenol, flavonoids, tannins, steroids and triterpenoids are known to have antioxidant effects. But Saponins are secondary metabolites that are suspected of causing damage to the kidneys. Saponins can cause hemolysis by influencing lipid bilayers in the protein membranes of red blood cells thus causing pore formation in the red blood cell membrane [7], [8]. In addition to saponins, the presence of hemoglobin, heme and iron is free in the tubules, causing cell damage and cell death [9].

Pulmonary damage occurs at every dose level of Nanoherbal haramontingalthough not much different (Figure 1). The accumulation of inflammatory cells in the alveolar wall causes thickening of the alveolar wall structure. The occurrence of damage in the T1 group is higher than T2 due the outside variables that cannot be controlled, such as the psychological condition of mice by the surrounding environment, such as the environment that is too noisy, giving repeated treatments, and fighting between mice. Damage is also evident in alveoli epithelial cells because of the relationship between alveoli and blood capillaries during gas exchangen the relationship of the alveolar is not tight and the shape of the lumen is irregular. From that we know that the administration of nanoherbal haramonting can cause significant damage to the lung cells every treatment with average 2 to 3 .

\section{Conclusion}

Effect of nanoherbal haramonting in lungs was significantly different from each treatment $(\mathrm{P}<0.05)$ but there was not significantly different in lung weight $(\mathrm{P}>0.05)$. Damage of alveoli epithelial cells on lung cells because of the relationship between alveoli and blood capillaries during gas exchangen the relationship of the alveolar is not tight and the shape of the lumen is irregular.

\section{Aknowledgement}

We are grateful to Directorate of research and community service, Directorate general of research and development, Ministry of research, Technology, and Higher Education in accordance with research and community service funding agreement on DRPM funds years 2019 (PDD- Number:11/E1/KP.PTNBH/2019).

\section{REFERENCES}

[1] Winotai, A., Tony, W., and Jhon, A.G., Herbivores in Thailand on Rhodomyrtus tomentosa (Myrtaceae), an invasive weed in Florida. Flor Ento. 88 (1):104- 105. 2005.

[2] Lai, T.N., Herent, M.F., Quetin-Leclercq, J., Nguyen, T.B., Rogez, H., Larondelle, Y., et al. Piceatannol, a potent bioactive stilbene, as major phenolic component in Rhodomyrtus tomentosa. Food Chem, 138(2-3):1421-30. 2013. 
[3] Limsuwan, S., Trip, E.N., Kouwen., T.R., Piersma, S., Hiranrat, A., Mahabusarakam, W., et al. Rhodomyrtone: A new candidate as natural antibacterial drug from Rhodomyrtus tomentosa. Phytomedicine, 16(6): 645-651. 2009.

[4] Geetha, K.M., Sridhar, C., Murugan, V., Antioxidant and Gastroprotective activities of Rhodomyrtus tomentosa (Ait.) Hassk. Int J Pharm Tech Res, 2:283-91. 2010.

[5] Rinku, Y.P., Shubhangi, A.P., Niranjan, D.C., Yogesh, N.P,. Herbal drug nanoparticles:advancementsin herbal treatment. Research J. Pharm. and Tech,11(1);421426. 2018.

[6] Situmorang, P.C., and Ilyas, S., Description of Testes Histology of Mus musculus after giving nano hebal Rhodomyrtus tomentosa (Haramonting). Asian J Pharm Clin Res, 11 issue 11. 2018.

[7] Baumann, E., Stoya, G., Volkner, A., Richter, W., Lemke, C., et al. Hemolysis of human erytrocytes with saponin affects the membrane structure. Acta histochemia. 2005.

[8] Gauthier, C., Legault, J., Girard-Lalancette, K., et al. Haemolytic activity, cytotoxicity and membrane cell permeabilization of semi-synthetic and natural lupane- and oleananetype saponins. Bioorg Med Chem.17:2002-8. 2009.

[9] Gutierrez, E., Egido, J., Rubio-Navarro, A., Buendia, I., Colio, L.M.B., et al. Oxidative stress, macrophage infiltration and CD163 expression are determinats of long term renal outcome in macrohematuria-induced acute kidney injury of IgA nephropathy. Nephron Clin Pract. 121:c42-c53. 2012. 